\title{
The Dilemma Whether to Produce Glued or Sawn Wooden Beams?
}

\section{Dilema: proizvoditi lijepljene ili piljene drvene grede?}

\author{
Professional paper • Stručni rad \\ Received-prispjelo: 15. 3. 2012. \\ Accepted-prihvaćeno: 15. 2. 2013. \\ UDK: 630*79; 674.093:65.011.4 \\ doi:10.5552/drind.2013.1211
}

\begin{abstract}
This article gives an overview of the contemporary development of wood production in the Czech Republic with the focus on the production of static structural members. This issue refers to literary sources of several authors dealing with the history and development of sawmills and adaptations of production strategies to the current trends. The study is based on information collected and assessed during the sawmill operations used by wood processing companies to make strategic decisions. Interaction of these input data and information acquired from the available literature indicates the possibility of development and specialization of the existing sawmills in upcoming years. Nearly 20 per cent of round timber is processed into static structural members, wooden beams. Considering the rising prices of input raw material, the question of the extent of cost-effectiveness and economy of sawn structural members arises. This article is aimed to clarify the seissues and compare the production costs of sawn and glued structural members used in common wooden constructions, such as roof frames, prefabricated houses, etc. This may have an impact not only on sawmills but also on the extent of use of thistype of wooden construction products. The question is whether the new restructuring of sawmills is coming or not?
\end{abstract}

Key words: production of static structural members, trends, production of BSH and KVH, sawn wooden beams, timber costs, wooden structures, cost-effectiveness.

SAŽETAK • U radu se daje pregled suvremenog razvoja drvne proizvodnje na području Republike Češke, s naglaskom na proizvodnju statičkih strukturnih elemenata.U pregledu se navode radovi nekoliko autora koji obrađuju povijest i razvoj pilana te strateške prilagodbe proizvodnje trendovima. Studija se koristi informacijama prikupljenima tijekom proizvodnje u pilani, na temelju kojih tvrtke za preradu drva donose strateške odluke. Povezivanjem tih ulaznih podataka i informacija iz dostupne literature dobiva se perspektiva razvoja i specijalizacije suvremenih pilana u idućim godinama. Gotovo 20 \% volumena oblog drva prerađuje se u statičke strukturne elemente - drvene grede. S obzirom na rast cijena ulazne sirovine, postavlja se pitanje isplativosti i ekonomičnosti proizvodnje piljenih strukturnih elemenata.Cilj je ovog članka objasniti tu problematiku i usporediti troškove proizvodnje piljenih i lijepljenih strukturnih elemenata koji se obično upotrebljavaju u drvenim konstrukcijama kao što su krovne konstrukcije, montažne kuće i sl. To može utjecati ne samo na proizvodnju u pilanama, već i na masovnost uporabe takvih vrsta drvenih građevnih proizvoda. Pritom se nameće pitanje hoće li doći do novog preustroja pilana ili ne.

Ključne riječi: proizvodnja statičkih strukturnih elemenata, trendovi, proizvodnja BSH i KVH greda, piljene drvene grede, troškovi drvne sirovine, drvene konstrukcije, isplativost.

\footnotetext{
${ }^{1}$ Author is assistant at the Faculty of Forestry and Wood Sciences, Czech University of Life Sciences, Prague, Czech Republik.

'Autor je asistent Fakulteta šumarstva i znanosti o drvu, Sveučilište bioloških znanosti u Pragu, Republika Češka.
} 


\section{INTRODUCTION}

\section{UVOD}

Every man dealing with wood processing is sure to be familiar with the timber market in the central Europe and the impact it has on wood processing companies. The current development does not meet the expectations of sawmills. The price of unprocessed timber and wood chips has been rising throughout the last two years and this fact has affected adversely the development of sawmills and advanced processing plants. During the past few years, sawmill production has gone through significant changes, and a large number of small-scale production plants were set up as a response to the changing demands of customers. Due to the new technology, such as the use of mobile saws, entrepreneurs had to redirect their production to a new way of cutting wood corresponding to new customers' requirements. However, as a result of the price of timber, a large number of companies have some serious financial difficulties and are on the verge of bankruptcy. However, such stagnation is equally damaging for some medium sawmills dealing with the production of structural members. Low demand for these products, which used to be a cash cow for many companies in the building market, resulted in the fact that nowadays woodcompanies are incapable of sustaining their volume of production, as the increase of end product prices is considerably lower than the rise of costs of input raw materials. Naturally, large-scale sawmills have also been facing the price increase of input materials and annual turnover drop. The dynamic expansion of sawmills in the Czech Republic has been replaced by stagnation or decline, which is still going on. Many companies have gone in search of new products hoping that a wider product range would make them more successful. A possibility might be the production of glued structural members. The objective of this article is to show how the Czech sawmills can benefit from such a production and why a glued static structural member (i.e. a structural member that bears static load) can re- place a sawn static structural member. The point I want to make here is that the production of glued static elements has the potential to initiate a new development in this business.

Lumbering has undergone great changes both in the working procedures and extraction technology in the past decade. We have been witnessing a rapidly increasing proportion of harvester logging and, as far as round $\operatorname{logs}$ are concerned, logs of 3 to $6 \mathrm{~m}$ have become the most common sawmill products. A large number of sawmill companies currently processing logs of this length and do not have to shorten them in further process of long round timber. Nowadays, they can purchase logs of the required quality, length and diameter. On the contrary, the companies processing long logs have to deal with the problem of requiring the assortment whose price has risen along with its demand. Looking for timber, they have to face its price increase caused by rising demand. The development of the sawmill product range is one of the reasons for the stagnation of the Czech sawmill industry. In the recent years (2007-2009), the average round timber price was EUR 65.5 (shipping included). In the following years, the price has rapidly increased to EUR 94 (shipping included). Such an astonishing increase of the round log price occurred in only two years and consequently many companies may go out of business. Figure 1 gives a survey of the recent development of round timber price, according to data of the three largest Czech wood industry companies.

As the German website (www.euwid-holz.de) reads, the development of the timber price in Poland, Germany, Austria, Sweden, Norway and Great Britain has been quite similar. The timber market has been at a standstill as well. So, for instance, a significant decline in lumber output can be noticed in Austria in the third quarter of the last year (www.euwid-holz.de).

Table 1 presents an overview of the Czech sawmills in order of their annual wood processing capacity. The data come from several sources (Pražan et al, 2007; Bomba et al, 2009). Based on the results of the

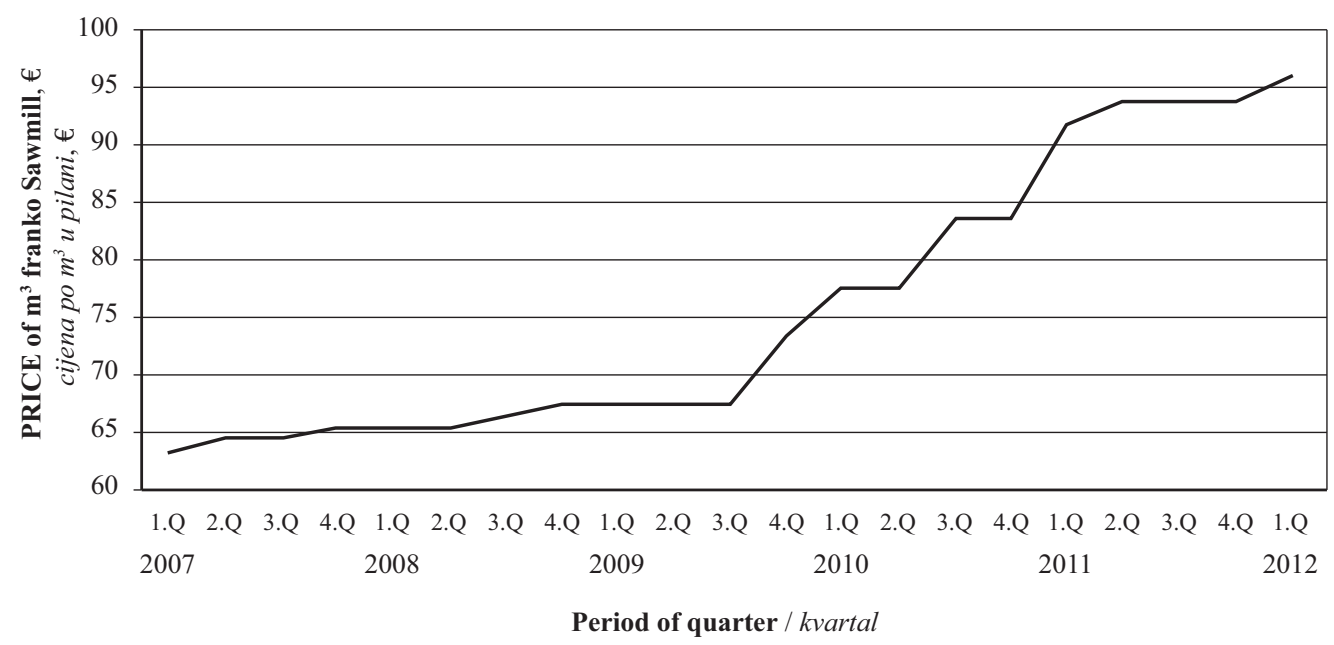

Figure 1 Development of round timber price in the Czech Republic

Slika 1. Rast cijena oblovine u Republici Češkoj 
Table 1 Survey of Czech sawmills based on their timber capacity (Pražan et al, 2007; Bomba et al, 2009)

Tablica 1. Podjela čeških pilana na temelju kapaciteta (Pražan et al, 2007; Bomba et al, 2009)

\begin{tabular}{|l|c|c|c|}
\hline $\begin{array}{l}\text { Company size } \\
\text { Veličina pilane }\end{array}$ & $\begin{array}{c}\text { Annual timber capacity, } \\
\text { thousands of cubic meters a year } \\
\text { Godišnji kapacitet proreza izražen } \\
\text { u tisućama kubičnih metara }\end{array}$ & $\begin{array}{c}\text { Annual timber output, cubic } \\
\text { meter a year } \\
\text { Godišnji izlaz piljene građe } \\
\text { izražen u kubičnim metrima }\end{array}$ & $\begin{array}{c}\text { Number of companies } \\
\text { within the category } \\
\text { Broj tvrtki }\end{array}$ \\
\cline { 2 - 4 } $\begin{array}{l}\text { The largest sawmills } \\
\text { najveće pilane }\end{array}$ & $200-1,100$ & $3,760,000$ & 5 \\
\cline { 2 - 4 } & $80-100$ & 370,000 & 4 \\
\hline $\begin{array}{l}\text { Medium sawmills } \\
\text { srednje velike pilane }\end{array}$ & $50-75$ & 295,000 & 30 \\
\hline $\begin{array}{l}\text { Small sawmills } \\
\text { male pilane }\end{array}$ & $20-50$ & $1,000,000$ & 60 \\
\hline $\begin{array}{l}\text { The smallest sawmills } \\
\text { najmanje pilane }\end{array}$ & $10-20$ & 750,000 & $1,400-2,000$ \\
\hline
\end{tabular}

research, assessment was made of most small or medium sawmills dealing with the production of sawn static structural members, or to be specific, the production of structural beams for building purposes. Building timber or beams for building purposes (roof frames, carpenter's structures, etc.) account for $52 \%$ of the output of these sawmills. This means that almost $20 \%$ of sawmill round timber is processed into structural lumber by the logging companies in the Czech Republic. It represents an inconceivable volume of timber that ends up in the building industry market. The falling demand for the sawn static structural members has a strong impact on small and medium wood processing companies. In addition to that, the growing price of the input raw material intended for cutting structural members and the struggle to break into this market caused the increase of the end prices of structural and building timber. The prices of end products, such as beams and structural timber, increased by $25 \%$ in average, although the price of the round wood entering the production rose by $43 \%$. The decrease of price of end products has forced the companies to put the product prices down. Consequently, this should have led to the optimization of timber processing, or possibly to a modification of the procedure technology. Unfortu- nately, due to low technology equipment of most small and medium plants, their managers or owners were not able to cut down on expenses and it resulted in the fact that such companies are on the verge of bankruptcy or going out of business.

As a consequence of ever increasing round wood prices, there is a serious increase of prices of end products, such as beams, structural elements of great size and length. These products are facing strong competition of products such as $\mathrm{KVH}$ (structural extended timber) and BSH (layered lamellar timber) at these times. According to Table 2, the products BSH are being available in the market at extraordinarily low prices. The general scheme of glued beam technology is shown in Figure 2.

Comparing the characteristics of $\mathrm{BSH}, \mathrm{KVH}$ beams and sawn beams, the glued beams proved to have significantly higher strength than the sawn beams, as shown in Table 3. Evidently, the use of glued structural members of $\mathrm{KVH}$ or BSH would save material in a common building construction (roof frames, ceilings, wooden constructions and so on). Another benefit of glued structural members is that it enables to select the visual aspect quality or industrial quality. What do those terms stand for? Visual aspect quality puts an emphasis on re-

Table 2 Survey of prices of BSH beams in Germany (http://www.euwid-holz.de)

Tablica 2. Pregled cijena BSH drvenih greda u Njemačkoj (http://www.euwid-holz.de)

\begin{tabular}{|c|c|c|c|c|c|}
\hline \multicolumn{6}{|c|}{$\begin{array}{l}\text { EUWID Preis mirror of BSH beams in Germany } \\
\text { December } 2011\end{array}$} \\
\hline in $€ / \mathrm{m}^{3}$ & 22.12 .2011 & 17.11 .2011 & 29.9.2011 & 2.12 .2010 & comp. $\%$ 2011/2010 \\
\hline \multicolumn{6}{|l|}{ Beams SI } \\
\hline $60 \times 100-160 \mathrm{~mm}$ & $390-400$ & $400-410$ & $405-410$ & $405-415$ & -4 \\
\hline $80 \times 100-200 \mathrm{~mm}$ & $385-400$ & $395-410$ & $400-410$ & $400-410$ & -3 \\
\hline $100 / 120 \times 120-320 \mathrm{~mm}$ & $380-385$ & $390-395$ & $390-395$ & $395-405$ & -4 \\
\hline $140 / 160 \times 140-400 \mathrm{~mm}$ & $375-380$ & $385-390$ & $385-390$ & $395-405$ & -6 \\
\hline $180 / 240 \times 200-400 \mathrm{~mm}$ & $370-380$ & $380-390$ & $385-390$ & $390-400$ & -5 \\
\hline Total price SI & $380-395$ & $390-405$ & $395-405$ & $400-410$ & -4 \\
\hline Total price nSI & $365-375$ & $375-385$ & $375-385$ & $385-395$ & -5 \\
\hline \multicolumn{6}{|l|}{ Commissions } \\
\hline Commissions SI & $395-410$ & $405-415$ & $405-420$ & $410-435$ & -5 \\
\hline \multicolumn{6}{|c|}{$\begin{array}{l}\text { Total price of beams SI/nSI of all standard profiles selected, length selected }<3 \mathrm{~m}^{3} \text { contract volume average purchase price } \\
\text { in stores, franco }\end{array}$} \\
\hline
\end{tabular}




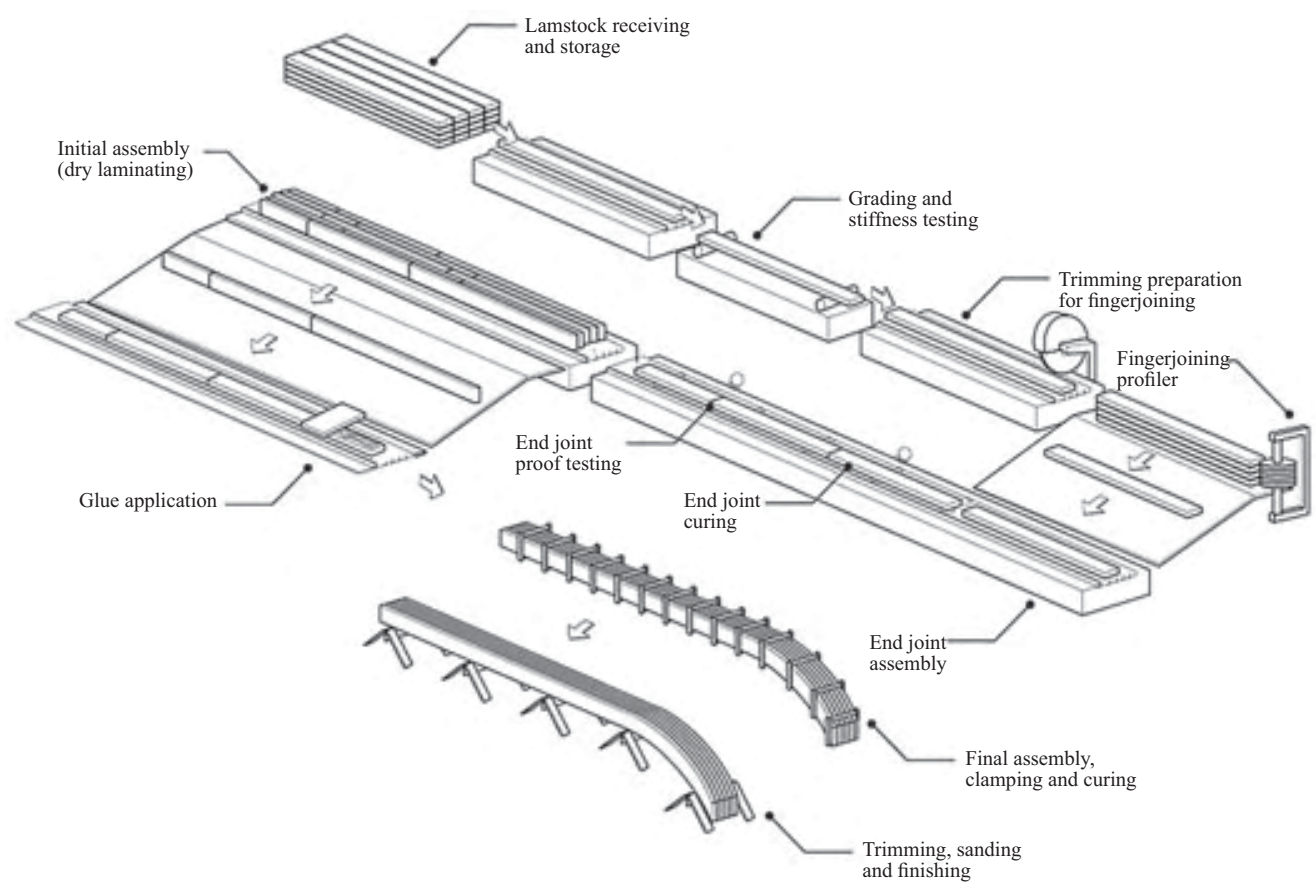

Figure 2 Manufacture of glued beams BSH (http://www.cwc.ca/index.php/en/wood-products/glulam/manufacture) Slika 2. Shema proizvodnog procesa lijepljenih greda BSH (http://www.cwc.ca/index.php/en/wood-products/glulam/ manufacture)

moval of flaws that could lower the strength as well as flaws that could lower the aesthetic quality or visual appearance of the beam. The greatest concerns are related to coloring, dark knots, outpouring of resin, etc. As opposed to it, industrial beam quality can include the above mentioned aesthetic flaws, which do not affect the strength. A significant aspect of the visual quality is the fact that follow-up processing, such as fixing of aesthetic flaws, is not necessary. Apart from the differences mentioned above, the end price makes the main difference between the visual aspect and industrial quality.

The quality of the industrial and visual aspects can also be found in sawn structural members. To be specific, the quality of the visual aspect does not include any roundness. The industrial beam usually includes such a roundness without lowering the timber strength. The roundness that originates from a round trunk provides higher strength based on the fact that wood fibers have not been broken by cutting. However, the industrial quality production of sawn beams was almost given up by lumbermen, although it considerably increases the cutting yield and lowers the end product costs. The reason lies in its poor marketability. Most customers consider that a sawmill manager wants to cheat them trying to sell them the beam below the required quality and strength because it has no edges. As there is almost no way to change the customer's mind, nothing else remains but to meet his demands.

\section{MATERIALS AND METHODS}

\section{MATERIJALI I METODE}

Twelve sawmill companies and three major manufacturers of $\mathrm{BSH}$ and $\mathrm{KVH}$ products were questioned directly for the purpose of this research, which was conducted in the period 2009-2011. In addition to it, contact was made with the structural engineer who carried out the calculation of the carrying capacity of sawn wood beams as well as glued beams KVH and BSH. Furthermore, other thirty sawmill companies were interviewed in order to collect information on the development of round timber purchase price in the years 2007-2012. This way significant and essential information was obtained with the aim to develop an analytical model for comparing the beams of $\mathrm{BSH}, \mathrm{KVH}$ and sawn beams.

On the basis of static calculations, comparison was made between the carrying capacity of glued beams and sawn wood beams. The static calculations were applied to the constructions of ten different house roofs in order to compare the material savings when using sawn beams or glued beams. Subsequently, comparison was made between the manufacturing technologies of sawn beams and glued beams in terms of the production costs and timber yield. These data were then transferred into the economic calculation of the end product price - for this purposes, a computing model was built complemented with timber yield data, the actual price of input materials and the actual production costs. The actual prices and production costs were obtained from the manufacturers in the Czech Republic. For the sake of objectivity, using different technological systems, only the above average values of the production expenses were used in the calculations. In conclusion of this research, comparison was made of all available information and general conclusions that might be used in practice.

\section{RESULTS AND DISCUSSION 3. REZULTATI I RASPRAVA}

According to Table 3, the glued structural members show better strength than sawn wood beams. This 
Table 3 Comparison of mechanical properties of sawn beams and glued beams of KVH and BSH (ČSN EN 1995-1-1, Praha 2006)

Tablica 3. Usporedba mehaničkih svojstava piljenih i lijepljenih greda, KVH i BSH

\begin{tabular}{|c|c|c|c|}
\hline Proporties / svojstva & Sawn wood $_{w=50 \%}$ & $\mathrm{KVH}_{w=15 \%}$ & BSH $_{w=12 \%}$ \\
\hline Bending strength $f_{\mathrm{m}, \mathrm{k}}, \mathrm{MPa} /$ Čvrstoća savijanja, $\mathrm{MPa}$ & 22 & 24 & 24 \\
\hline $\begin{array}{l}\text { Fracture strength parallel with fibers } f_{\mathrm{t}, 0, \mathrm{k}}, \mathrm{MPa} \\
\check{C} \text { vrstoća loma paralelno s vlakancima, } \mathrm{MPa}\end{array}$ & 13 & 14 & 16.5 \\
\hline $\begin{array}{l}\text { Fracture strength vertical to fibers } f_{\mathrm{t}, 90, \mathrm{k}}, \mathrm{MPa} \\
\check{C} \text { vrstoća loma okomito na vlakanca, MPa }\end{array}$ & 0.5 & 5 & 0.4 \\
\hline $\begin{array}{l}\text { Compressive strength parallel with fibers } f_{\mathrm{c}, 0, \mathrm{k}}, \mathrm{MPa} \\
\text { Cvrstoća na tlak paralelno s vlakancima, } \mathrm{MPa}\end{array}$ & 20 & 21 & 24 \\
\hline $\begin{array}{l}\text { Compressive strength vertical to fibers } f_{c, 90, \mathrm{k}}, \mathrm{MPa} \\
\text { Čvrstoća na tlak okomito na vlakanca, MPa }\end{array}$ & 2.4 & 2.5 & 2.7 \\
\hline Shear strength $f_{\mathrm{v}, \mathrm{k}}, \mathrm{MPa} /$ Čvrstoća na smicanje, $\mathrm{MPa}$ & 2.4 & 2.5 & 2.7 \\
\hline
\end{tabular}

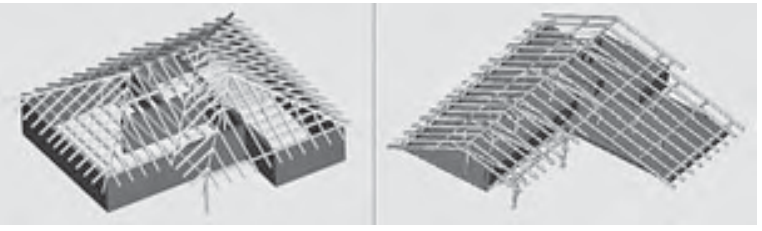

Figure 3 Roof construction

Slika 3. Krovne konstrukcije

implies that it is possible to economize with wood material used in building industry. To prove this point, the static calculation was carried out in order to compare sawn beams and glued beams under the same static load and the same span. To provide practical evidence, the computing was accomplished on several construction models of a no name company. Gable and hip roof constructions of bungalows including a habitable attic and a wooden ceiling were also considered. Using statistical computing tools, the expected economic effects of the material used for the construction in question were proven with the roof frame or the ceiling load. A better use was confirmed of both $\mathrm{KVH}$ and $\mathrm{BSH}$ beams compared to sawn wood beams. However, the efficiency of KVH beams was only proven if used for structural members of the roof frame such as rafters and purlins of small size. Given the range of commonly produced dimensions of KVH beams, it was not possible to substitute all structural members of calculated constructions. In contrast to it, with the help of commonly available dimensions of BSH beams, the structural members in question could be fully replaced.

All structural elements of the roof frame such as rafters, purlins, ribbands, collar-beams and piers were gradually substituted by the glued BHS beams. In this way significant savings of material were achieved ranging from 12.5 to $25 \%$ of the total volume. Table 4 can be used as an illustration, as it presents the results of all static calculations of the structural members made of sawn beam and BSH beam. Positive economic effects can be readily identified.

Taking into account the economic effects, comparison was made of production costs of sawn wood beams and glued BSH beams based on static calculations. If the end price of $\mathrm{BSH}$ products used for a wooden construction is lower or equal, this new strategy can have an impact on future trends and development of sawmills.

The production of glued and sawn beams is already characterized by the process of sawing. Comparing all the three technologies of beam production, most similarities are found between the sawn prism and glued prism of $\mathrm{KVH}$, although there are some differences as well. On the contrary, the manufacturing of $\mathrm{BSH}$ beams is completely different because it is made of 40-52 mm thick lamellas. It is the first variance that can influence cutting.

Table 4 Comparison of static computation results for sawn and glued BSH beams

Tablica 4. Usporedba statičkih izračuna za piljene i lijepljene BSH grede

\begin{tabular}{|c|c|c|c|c|c|c|c|c|c|c|c|}
\hline & \multicolumn{5}{|c|}{ Sawn wood/ Piljena greda } & \multicolumn{5}{|c|}{ BSH / Lamelirana greda BSH } & \multirow{2}{*}{$\begin{array}{c}\text { Economy } \\
\text { Ušteda } \\
\% \\
\end{array}$} \\
\hline & $\begin{array}{c}b \\
\mathrm{~mm}\end{array}$ & $\begin{array}{c}h \\
\mathrm{~mm}\end{array}$ & $\begin{array}{c}l \\
\mathrm{~mm}\end{array}$ & $\begin{array}{c}S \\
\mathrm{~m}^{2}\end{array}$ & $\begin{array}{c}V \\
\mathrm{~m}^{3}\end{array}$ & $\begin{array}{c}b \\
\mathrm{~mm}\end{array}$ & $\begin{array}{c}h \\
\mathrm{~mm}\end{array}$ & $\begin{array}{c}l \\
\mathrm{~mm}\end{array}$ & $\begin{array}{c}S \\
\mathrm{~m}^{2}\end{array}$ & $\begin{array}{c}V \\
\mathrm{~m}^{3}\end{array}$ & \\
\hline \multirow[t]{3}{*}{ Purlin / Sljeme } & 180 & 260 & 8000 & 0.047 & 0.3744 & 160 & 260 & 3000 & 0.0416 & 0.3328 & 12.5 \\
\hline & 180 & 240 & 7000 & 0.043 & 0.3024 & 160 & 240 & 7000 & 0.0384 & 0.2688 & 12.5 \\
\hline & 160 & 200 & 5400 & 0.032 & 0.1728 & 140 & 200 & 5400 & 0.028 & 0.1512 & 14.3 \\
\hline \multirow[t]{3}{*}{ Rafter / Krovna greda } & 100 & 180 & 7000 & 0.018 & 0.126 & 80 & 180 & 7000 & 0.0144 & 0.1008 & 25.0 \\
\hline & 100 & 160 & 6000 & 0.016 & 0.096 & 80 & 160 & 6000 & 0.0128 & 0.0768 & 25.0 \\
\hline & 120 & 180 & 8000 & 0.022 & 0.1728 & 80 & 200 & 3000 & 0.016 & 0.128 & 35.0 \\
\hline \multirow[t]{2}{*}{ Pier / Stup } & 160 & 160 & 3000 & 0.026 & 0.0768 & 152 & 152 & 3000 & 0.0231 & 0.0693 & 10.8 \\
\hline & 140 & 140 & 3000 & 0.020 & 0.0588 & 135 & 135 & 3000 & 0.0182 & 0.0546 & 7.5 \\
\hline
\end{tabular}

$b$ - beam width / širina grede; $h$ - beam height / visina grede; $l$ - beam length / duljina grede; $\mathrm{S}$ - cross-sectional area / površina poprečnog presjeka; $V$ - beam volume / volumen grede. 
Whereas cutting of sawn and KVH beams show similarities, their manufacturing is completely different. The first difference lies in drying. The sawn beam is left to dry out spontaneously, while the KVH beam is dried artificially to the moisture of $15 \pm 3 \%$. The process of drying indicates that during the production of KVH beams, the cutting should go through the beam centre in order to cut out the beam pith. If the pith is left inside the beam, it can leave wider cracks after drying. During manufacturing of structural timber, beams with cracks must be shortened in order to sustain the strength of the final product. The best way of manufacturing KVH beams is to remove the pith by inserting a central plank or board. Unfortunately, putting any component inside $\mathrm{KVH}$ timber influences adversely the size of the prism loading area. This loading area is growing and therefore the round timber with bigger pin diameter must be chosen. It lowers the timber yield during the production of $\mathrm{KVH}$ prism and raises the production costs. With the price of round timber, which is rising proportionally to the increase of round timber diameter, the costs of input raw material for the production of KVH prisms are also increasing. Therefore, the money spent on round timber, cutting, drying and manufacturing of $\mathrm{KVH}$ reaches the same value or higher than the production of BSH prisms.

Subsequently, the costs were compared of entry raw material intended for the production of $\mathrm{KVH}$ and BSH prisms with dimensions 100x180x6000 mm, which can be used for a common roof rafter. For cutting KVH, which requires cutting through the pith and putting two prisms next to each other, round timber is needed with the $\operatorname{cog}$ diameter of $31 \mathrm{~cm}$ (bark excluded) and the length of $3.7 \mathrm{~m}$ (based on available technology). This length can more or less cover the cogged joint and shortening of flaws. On the contrary, BSH beam can be cut into 5 pieces of round timber with $\operatorname{cog}$ diameter of $13 \mathrm{~cm}$ and the length of $3 \mathrm{~m}$. Despite the fact that it is necessary to saw more logs from large round timber volume, significant economic effects can be achieved, reaching approximately EUR 16, due to lower raw material costs (the difference in thickness 1a:2b).

Comparing the cutting of timber intended for manufacturing of sawn prisms and $\mathrm{KVH}$ or BSH prisms of the same dimensions, the following conclusion was made. Assuming that sharp-edged timber is produced with the help of standard technology, cutting of 20-55 $\mathrm{cm} \operatorname{cog}$ diameter by frame saw and of $10-20 \mathrm{~cm} \operatorname{cog}$ diameter by prism or aggregate assembly line, the production of $\mathrm{KVH}$ beams would have the biggest cog diameter of cut timber as shown in Figure 3. This fact arises the question of production effectiveness of $\mathrm{KVH}$ beams.

Apart from cutting, the drying process is also crucial as due to large cutting dimensions it must be performed slowly so as to prevent creating big cracks. Drying increases the costs 2.5 to 3.5 times compared to lamellar cutting intended for the production of BSH beams (Janik, 1960). The current rise of energy prices has an adverse effect on the costs of KVH prism production. The expenses of drying of lamellar cutting are approximately EUR 15.5 for 1 cubic meter down to a

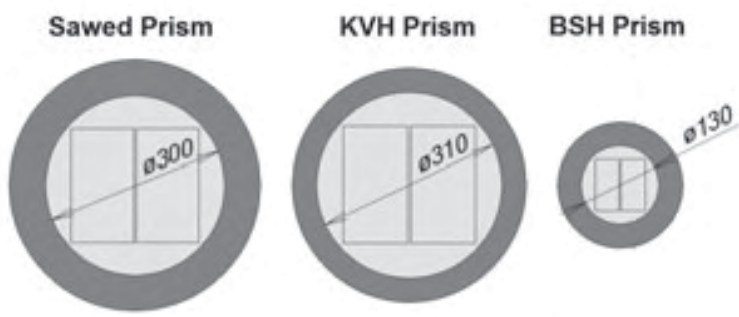

Figure 3 Different crosscuts

Slika 3. Razlike u presjeku piljenja

moisture of $10 \%$, whereas the cost of a $\mathrm{KVH}$ beam dried down to a moisture of $15 \%$ is approximately EUR 52. The above are average prices and differ with respect to cutting dimensions, type of heating, drying procedure technology, input moisture, outside temperature, etc. Anyway, the manufacturing costs of KVH prisms reach the expenses of manufacturing BSH prisms, which is a far more complex and demanding procedure. The question remains whether it is still convenient to produce structural beams $(\mathrm{KVH})$ for building purposes and carpenter structures since the economic effects of the use of KVH of larger dimensions are not up to our expectations.

The question of production effectiveness of $\mathrm{KVH}$ prism is and will be left to answer by the very manufacturers of this product. The following paragraphs are focused on BSH beams and sawn static beams, particularly an illustrative comparison, optimization and production calculations.

For comparing a sawn beam and a glued beam (BSH), it is necessary to consider all their characteristics. The consideration must be based on the following facts. The sawn beam has to be cut with an excess for drying. Such excesses are determined by the Czech State Norm (CSN 49 1109). The glued timber is dried (the temperature is usually above $60^{\circ} \mathrm{C}$ ), meaning that after such drying no insect embryos or fungi can be left hidden. This is why at least the costs of wood impregnation (Kozárek, 2009) via soaking must be added to the end price of the sawn beam. The BSH beam has no flaws, such as excessive or rotten knots, which would decrease its strength. BSH beams can be ruled out because they are made in accordance with CSN EN 386. Therefore, the use of sawmill round timber of $A B$ quality guarantees to eliminate all flaws that can reduce the strength. Another advantage of the BSH beam is the planed surface. This is why it can also be used in constructions requiring visual quality. When comparing the beam properties, the roof construction with visual elements was taken into consideration, and hence the price of sawn beams has been increased by the price of planing.

Czech state standards were used for the calculation and optimization of manufacturing of sawn beams and glued BSH beams. These standards specify excesses required due to drying, timber takeover, BSH prism production procedures, sawn prism production procedures (Fronius, 1989; Friess, 2003), etc. According to these standards it is possible to make impartial judgments of timber and manufacturing parameters. The 
Table 5 Dependence of the yield on diameter and length (Fronius, 1991)

Tablica 5. Ovisnost iskorištenja o promjeru i duljini trupaca (Fronius, 1991)

\begin{tabular}{|c|c|c|c|c|c|c|c|c|}
\hline $\begin{array}{c}\text { Tenon } \\
\text { Promjer na } \\
\text { tanjem kraju } \\
\mathrm{cm}\end{array}$ & $\begin{array}{c}\text { Area } \\
\text { Površina }\end{array}$ & $\begin{array}{c}\text { Side } \\
\text { Strana }\end{array}$ & $\begin{array}{c}\text { Square area } \\
\text { Površina } \\
\text { kvadrata } \\
\mathrm{m}^{2}\end{array}$ & $\begin{array}{c}\text { Yield } \\
\text { Iskorištenje }\end{array}$ & \multicolumn{2}{|c|}{$\begin{array}{c}\text { Maximum theoretical yield depending on length } \\
\text { Najvée teorijsko iskorištenje ovisno o duljini trupca, }\end{array}$} \\
\hline & & & & \multicolumn{4}{|c|}{$\%$} \\
\hline 14 & 0.015394 & 9.90 & 0.0098 & 63.66 & 51.93651 & 48.74120 & 45.83195 & 43.17560 \\
\hline 16 & 0.020106 & 11.31 & 0.0128 & 63.66 & 53.21622 & 50.30082 & 47.61860 & 45.14534 \\
\hline 18 & 0.025447 & 12.73 & 0.0162 & 63.66 & 54.24452 & 51.56620 & 49.08145 & 46.77206 \\
\hline 20 & 0.031416 & 14.14 & 0.0200 & 63.66 & 55.08879 & 52.61320 & 50.30082 & 48.13760 \\
\hline 22 & 0.038013 & 15.56 & 0.0242 & 63.66 & 55.79429 & 53.49374 & 51.33261 & 49.29984 \\
\hline 24 & 0.045239 & 16.97 & 0.0288 & 63.66 & 56.39262 & 64.24452 & 52.21687 & 60.30082 \\
\hline 26 & 0.053093 & 18.38 & 0.0338 & 63.66 & 56.90644 & 54.69222 & 52.98307 & 51.17182 \\
\hline 28 & 0.061575 & 19.80 & 0.0392 & 63.66 & 57.35247 & 55.45666 & 53.65331 & 51.93651 \\
\hline 30 & 0.070686 & 21.21 & 0.0450 & 63.66 & 57.74329 & 55.95291 & 54.24452 & 52.61320 \\
\hline 32 & 0.080425 & 22.63 & 0.0512 & 63.66 & 58.08854 & 56.39262 & 54.76989 & 53.21622 \\
\hline 34 & 0.090792 & 24.04 & 0.0578 & 63.66 & 58.39575 & 56.78491 & 55.23982 & 53.75694 \\
\hline 36 & 0.101788 & 25.46 & 0.0648 & 63.66 & 58.67088 & 57.13707 & 55.66262 & 54.24452 \\
\hline 38 & 0.113411 & 26.87 & 0.0722 & 63.66 & 58.91870 & 57.45493 & 56.04505 & 54.68643 \\
\hline 40 & 0.125664 & 28.28 & 0.0800 & 63.66 & 59.14308 & 57.74329 & 56.39262 & 55.08879 \\
\hline
\end{tabular}

data on manufacturing of glued structural members and input costs of cutting is gained from the statistics made by three companies operating in the Czech Republic and Germany.

The possibility of reducing the production price of long beams lies in cutting, trunk convergence and price of input round timber. Based on the statistical analysis of electronic takeovers of timber carried out in six companies, it can be affirmed that the convergence of spruce round timber commonly exceeds $1 \mathrm{~cm} / \mathrm{m}$. This finding confirms the affirmation that the yield of central beam falls proportionally to its length. For the purpose of objectivity, the theoretical convergence value of $1 \mathrm{~cm} / \mathrm{m}$, set by the Czech state standard, was lowered in our calculations proportionally to the beam length especially in case sharp-edged beams (with no rounding). No claim is made that convergence of short cuttings does not equally affect the yield. The effect is absolutely the same, yet the yield of central cutting is a little higher. It can be concluded that in cutting long static structural members the yield falls but the price of the very product rises. As opposed to it, in cutting the lamellas for the production of BSH beams, short round timber can be used because lamellas can be extended up to the required length with the help of cogged joints in the production of beams. For BSH beams with smaller diameter, cutting can be made with smaller tenon diameter and the length of 3-4 m. In this way, the costs of input round timber are reduced. Despite the lower yields achieved with smaller diameters of round timber, it is always suitable to select such round logs because their input price is significantly lower. Proportionality of the yield to the diameter and length is presented in Table 5 (Fronius, 1991). The difference between the price of cutting long beams and lamellas can pay the manufacturing of the BSH glued beams.

Based on the above, many calculations have been executed considering timber cutting at the length of 3 or 4 meters. Subsequently, it was concluded that a good price difference can be achieved in cutting provided that the cut beam is longer than 5 meters. Price difference of input raw materials grows with the increase of the beam length and the production of BSH beams is becoming less costly than the production of sawn beam. This is the turning point when, due to its economic efficiency, the production of glued beams instead of sawn beams started to be taken into consideration. This is why the following comparison and calculation will be only carried out with the beams longer than 5 meters.

The illustrative example of calculation and comparison is made with standard dimensions of a rafter at the crosscut of $100 \times 180 \mathrm{~mm}$ and the length of 7 meters. The static computing proves that a glued beam with the diameter of $80 \times 180 \mathrm{~mm}$ and the length of $7 \mathrm{~m}$ can be used for supporting the same load. Using the glued prisms brings the savings of the volume of $0.025 \mathrm{~m}^{3}$ per 1 piece. As for the whole roof frame construction, in which 34 pieces are used, the saving of $0.857 \mathrm{~m}^{3}$ can be achieved. Compared with sawn beams, manufacturing of BSH beams with the diameter of $80 \times 180 \times 7000$ $\mathrm{mm}$ requires more timber. This is the result of excesses caused by planing and drying. In spite of that, the input timber costs of manufacturing BSH beams are lower than the costs of sawn beams.

As far as cutting is concerned, the glued beam is produced from lamellas with the diameter of $40 \times 90$ $\mathrm{mm}$ and dimensions installed $38 \times 85 \mathrm{~mm}$ (the excess for drying is specified by the standard). The installed size is cut to final dimensions $36 \times 80 \mathrm{~mm}$ by planing. The thickness of $36 \mathrm{~mm}$ is obtained after manufacturing of an "endless" lamella and the width of $80 \mathrm{~mm}$ after sticking a beam. As opposed to that, the sawn beam is manufactured with the excess intended for drying, specified by the standard, and with the excess for planing, and namely the sawn dimensions of $107 \times 189$ $\mathrm{mm}$. Just one prism is cut and then it is split into two beams. Thereby, an almost square cut is obtained rais- 
ing the yield of central cutting. To make such cutting and manufacture sharp-edged lumber, it is necessary to provide round timber with the length of $7 \mathrm{~m}$ and pin diameter of $31 \mathrm{~cm}$.

The volume of round timber intended for manufacturing beams is $0.654 \mathrm{~m}^{3}$. The price of the beam is derived from the cutting calculation. The total is reached by summing the average cutting price per $1 \mathrm{~m}^{3}$ (in the Czech Republic it comes to EUR 32.6), and the volume of the cut piece multiplied by the central cutting yield (43.28\%) and the input price of round timber (93.8 EUR $\left./ \mathrm{m}^{3} \times 0.654 \mathrm{~m}^{3}\right)$. The price of two central cutting beams equals EUR 48.9. After adding the price of planing $\left(2 \mathrm{EUR} / \mathrm{m}^{2}\right)$, the total price of EUR 16.9 is obtained. Then the price of colorless impregnation is added, which provides protection against ligniperdous insects and fungi. The going price is $20.4 \mathrm{EUR} / \mathrm{m}^{3}$ so the total cost of impregnation amounts to EUR 5.4. Altogether the price of two beams installed with the dimensions of 100x180 mm comes to EUR $48.9+$ EUR 16.9 + EUR 5.4=EUR 71.2. It corresponds to the price of EUR 279 recalculated to $1 \mathrm{~m}^{3}$ of timber according to dimensions installed. Cost price and standard profit of about $20 \%$ makes the total price of $334.6 \mathrm{EUR} / \mathrm{m}^{3}$.

The manufacturing of BSH beams is again an issue. It is necessary to make a sufficient quantity of lamellas with the dimensions 40x90 mm. There are two options for manufacturing the beam. The first is to cut a thin round timber, namely lamellas of $40 \times 90 \mathrm{~mm}$, and the second is to cut a thick round timber, lamellas of $42 \times 180 \mathrm{~mm}$. It can raise the question why to cut these lamellas to a specific size when it is possible to glue the prism of the dimension 166x180 mm and then split it up and plane. Unfortunately, this alternative is financially more demanding. This leads back to the idea of cutting the lamellas to the size of $40 \times 90 \mathrm{~mm}$. Two lamellas have to be cut in parallel in order to get sharp-edged cuttings. Round timber with the length of $3 \mathrm{~m}$ or $4 \mathrm{~m}$ and of $\mathrm{C}$ quality is used for cutting. When calculating timber required for the production of lamellas, bonding timber must also be taken into account and it ranges from 78 to $85 \%$, planing excluded (cutting the flaws). Better quality of timber results in a better yield. In this paper, the yield of $78 \%$ will be taken into account. To achieve objectivity and efficiency, the computing is related to the manufacturing of two beams. It means that 15 pieces needed to be cut out of a 3 meter long round timber with the pin diameter of $13 \mathrm{~cm}$, or 11.2 pieces out of 4 meter long round timber. The volume of cut round timber is $0.741 \mathrm{~m}^{3}$ with $3 \mathrm{~m}$ round timber and $0.793 \mathrm{~m}^{3}$ with $4 \mathrm{~m}$ round timber. Despite the larger volume of round timber compared to the manufacturing of sawn beams, the cost of timber is considerably lower. This is due to the fact that the price of round timber for the $\mathrm{C}$ quality with the thickness class $1 \mathrm{a}$ amounts to EUR 59.2. Hereby, the difference can be seen between input raw material needed for glued beams and sawn beam: 93.8 EUR/m $/ \mathrm{m}^{3}$ against $59.2 \mathrm{EUR} / \mathrm{m}^{3}$. Although the consumption of input round timber is higher by approximately $0.139 \mathrm{~m}^{3}$, the savings are still considerable. The price of timber, assuming the same price of cutting, comes to EUR 43.3 with 3 m round timber and EUR 45 with $4 \mathrm{~m}$ timber. However, to reach the final product, the BSH beam, there is still a long way to go. The cut timber needs to get dry. Drying is done according to the set of rules for this procedure, namely at the maximum temperature of $90^{\circ} \mathrm{C}$. Based on our own statistics (information from 5 woodworking companies) of timber drying, the average price of drying $40 \mathrm{~mm}$ thick timber is approximately $16.5 \mathrm{EUR} / \mathrm{m}^{3}$. Then timber is processed with the aim to eliminate the flaws such as knots, cross-grains, rot, etc. After that, timber is planed to the desired thickness and shortened to desired length. The adhesive is then applied on each lamella and then comes the pressing in a vertical press. After pressing, the beam is planed to the right thickness in order to match the second set of dimensions. In order to calculate the production of BSH beams, renowned manufacturers of these products were contacted and they provided the data for the calculation and optimization. The computing includes melamine-formaldehyde adhesive and the recommended layer applied on $1 \mathrm{~m}^{2}$, which ranges around $380 \mathrm{~g} / \mathrm{m}^{2}$. The amount of adhesive consumed in the production of two beams comes to the price of EUR 4.1. Production costs for $1 \mathrm{~m}^{3}$ of glued structural member range between 40 and $62 \mathrm{EUR} / \mathrm{m}^{3}$ depending on the dimensions of the manufactured product. The price of this manufacturing section was statistically derived and it is $49-53 \mathrm{EUR} / \mathrm{m}^{3}$. For the purpose of this paper, the higher value $\left(53 \mathrm{EUR} / \mathrm{m}^{3}\right)$ is taken into account and therefore the manufacturing price of EUR 62.6 is reached for two beams. By adding the profit of $20 \%$, the price of $373 \mathrm{EUR} / \mathrm{m}^{3}$ of a glued $\mathrm{BSH}$ beam is obtained on the condition that 3 meter round timber is used and $383 \mathrm{EUR} / \mathrm{m}^{3}$ if $4 \mathrm{~m}$ round timber is used. The price of the glued BSH beam can be checked in Table 2, where the marketable price of the beams with the dimensions of $80 \times 100-200 \mathrm{~mm}$ amounts to around EUR 385.

The price difference of comparable products, as far as their quality and load is concerned, such as sawn and glued BSH prisms, is approximately EUR 48 in favor of sawn beams. It means that the production of the glued BSH beams still seems to be less profitable. However, if the price is calculated with respect to consumption of the material consumed during construction, a very interesting conclusion can be made. An actual roof frame breakdown was used to illustrate the comparison of volumes and prices of the sawn and glued BSH beams, longer than $5 \mathrm{~m}$, as shown in Table 6 . The other beams were kept in the form of sawn static structural members.

Based on the comparison, computing and calculations mentioned above, certain conclusions can be drawn. These conclusions can have an impact on the decision-making as to whether to produce the glued or sawn beams. As mentioned above, a limiting factor is given by the length of the beam. The limiting length from which it is profitable to manufacture glued beams is 5 meters. Furthermore, it is convenient to use glued beams instead of sawn beams with larger diameter exposed to bending and spacing from square section cut- 
Table 6 Overview of savings: sawn beam vs. glued BSH beam

Tablica 6. Pregled ušteda: usporedba piljenih i lijepljenih BSH greda

\begin{tabular}{|c|c|c|c|c|c|c|c|c|c|c|c|c|}
\hline \multirow{2}{*}{$\begin{array}{l}\text { Structural } \\
\text { Member } \\
\text { Strukturni } \\
\text { element }\end{array}$} & \multicolumn{5}{|c|}{$\begin{array}{c}\text { Sawn beam } \\
\text { Piljena greda }\end{array}$} & \multicolumn{3}{|c|}{$\begin{array}{c}\text { Glued beam } \\
\text { Lijepljena greda }\end{array}$} & \multicolumn{2}{|c|}{$\begin{array}{c}\text { Prism price } \\
\text { Cijena prizme }\end{array}$} & \multicolumn{2}{|c|}{$\begin{array}{c}\text { Total costs } \\
\text { Ukupni trošak }\end{array}$} \\
\hline & $\begin{array}{c}\text { Height } \\
\text { Visina } \\
\mathrm{m}\end{array}$ & $\begin{array}{c}\text { Width } \\
\text { Širina } \\
\text { m }\end{array}$ & $\begin{array}{c}\text { Lenght } \\
\text { Duljina } \\
\mathrm{m}\end{array}$ & $\begin{array}{c}\text { Pieces } \\
\text { Kom. }\end{array}$ & $\begin{array}{c}\text { Volume } \\
\text { Volumen } \\
\mathrm{m}^{3}\end{array}$ & $\begin{array}{c}\text { Height } \\
\text { Visina } \\
\mathrm{m}\end{array}$ & $\begin{array}{l}\text { Width } \\
\text { Širina } \\
\mathrm{m}\end{array}$ & $\begin{array}{c}\text { Saving } \\
\text { Ušteda } \\
\%\end{array}$ & $\begin{array}{c}\text { Sawn } \\
\text { Piljena } \\
€ / \mathrm{m}^{3}\end{array}$ & $\begin{array}{l}\mathrm{BSH} \\
€ / \mathrm{m}^{3}\end{array}$ & $\begin{array}{c}\text { Sawn } \\
\text { Piljena } \\
€\end{array}$ & $\begin{array}{c}\mathrm{BSH} \\
€\end{array}$ \\
\hline Joist / greda & 0.180 & 0.260 & 9.50 & 15 & 6.669 & 0.160 & 0.260 & 11 & 338 & 379 & 2254 & 2247 \\
\hline Purlin / sljeme & 0.160 & 0.200 & 7.80 & 5 & 1.248 & 0.140 & 0.200 & 13 & 345 & 391 & 431 & 434 \\
\hline $\begin{array}{l}\text { Prop } \\
\text { potporanj }\end{array}$ & 0.140 & 0.160 & 4.10 & 8 & 0.735 & & & & & & & \\
\hline Pier / stup & 0.140 & 0.140 & 2.00 & 4 & 0.157 & & & & & & & \\
\hline $\begin{array}{l}\text { Wall beam } \\
\text { zidna greda }\end{array}$ & 0.140 & 0.100 & 36.00 & 1 & 0.504 & & & & & & & \\
\hline $\begin{array}{l}\text { Rafter } \\
\text { krovna greda }\end{array}$ & 0.100 & 0.180 & 7.00 & 34 & 4,284 & 0.080 & 0.180 & 20 & 335 & 383 & 1435 & 1313 \\
\hline $\begin{array}{l}\text { Rafter } \\
\text { krovna greda }\end{array}$ & 0.100 & 0.180 & 6.10 & 8 & 0.878 & 0.080 & 0.180 & 20 & 335 & 383 & 294 & 269 \\
\hline $\begin{array}{l}\text { Skew prop } \\
\text { kosi potporanj }\end{array}$ & 0.100 & 0.120 & 1.70 & 6 & 0.122 & & & & & & & \\
\hline Collet / kolut & 0.080 & 0.180 & 7.20 & 30 & 3,110 & 0.070 & 0.180 & 13 & 338 & 405 & 1051 & 1119 \\
\hline Collet / kolut & 0.060 & 0.160 & 2.00 & 18 & 0.346 & & & & & & & \\
\hline Sum / zbroj & & & & & & & & & & & 5465 & 5382 \\
\hline
\end{tabular}

ting. Cutting such beams decreases the yield and increases the production costs.

It can be concluded that it is advantageous to manufacture glued beams if the height and width ratio is approximately $2: 1$. In such a case, the round timber with significantly smaller tenon diameter can be used for cutting compared to cutting of sawn beams. Trying to get as close as possible to square cutting, cutting two beams in one cutting is preferred. This way, the costs of input raw material can be considerably lower, and by using prism or aggregate technology, cutting costs can also be decreased.

On the contrary, the selection of glued beams is not quite convenient for manufacturing piers because most of them are used as angle braces, less than 5-meter long. In case of cutting round timber under $5 \mathrm{~m}$, the economy achieved by trunk convergence is not reached and this is why the economic effect of cutting is markedly lower. The limiting factor for manufacturing piers is the volume economy (influence of different strengths of two referred products), which is confirmed by the pier dimensions of $220 \times 220 \times 3000 \mathrm{~mm}$ when the economic effect comes to $17 \%$ of the volume. Shorter piers with smaller diameters do not yield effects that could justify the replacement of sawn piers by glued piers.

In producing roof frame structures intended for traditional family houses and industrial buildings, 50$80 \%$ of sawn beams can be replaced by glued beams. In all-wooden structures such as prefabricated family houses, pergolas, garages, etc. this value is lowered to the range of 20 to $50 \%$. The decrease is caused by a small span of such constructions and a large number of piers and crosswise beams of short span used in such constructions. What matters is the quantity of structural members and their parameters made by a particular sawmill. On the basis of available data, it can be stated that sawmills can replace 37 to $63 \%$ of sawn beams by glued beams. This volume is large enough to make the sawmill managers consider the significance of glued lamellar structural members (BSH). These findings could lead to a drastic change of sawmill development in the Czech Republic and Europe.

\section{CONCLUSION}

4. ZAKLJUČAK

Although it is not possible to achieve economic effects in producing each glued structural member, the costs are nearly equal and this fact could induce the sawmill managers to consider the possibility of producing structural elements and introduce serious changes in sawmill production. The optimization of producing BSH beams can result in further economic effects and however it has been ruled out. Anyway, using the glued beam technology, the sawmill managers could meet the orders of large diameter and span structures.

To conclude, in producing sawn timber for wooden constructions such as roof frames or whole prefabricated houses, it is effective to combine sawn and glued structural members despite the rising price of round timber. Such a change can yield higher profit or financial effects, which will be appreciated by end costumers.

The question, whether the glued beams should be produced by sawmills or purchased from renowned producers, remains to be answered by sawmill managers.

\section{REFERENCES}

\section{LITERATURA}

1. Bomba, J.; Friess, F. 2009: Vývoj pilařství v českých zemích. In Lesnická práce: časopis pro lesnickou vědu a praxi, 2 (89): 
2. Friess, F. 2003: Pilařské zpracování dřeva II., materiály k přednáškám. Česká zemědělská univerzita v Praze. Fakulta lesnická a dřevařská, p. 22

3. Janik, W., 1960: Handbuch der Holztrocknung, Fachbuchverlag, Leipzig, 208 pp.

4. Fronius, K., 1991: Gatter Nebenmaschinen Schnitt- und Restholz- behandlung, DRW-Verlag Stuttgart, Stuttgart.

5. Fronius, K., 1989: Spaner, Kreissägen, Bandsägen : Arbeiten und Anlagen im Sägewerk. Band2, DRW-Verlag Stuttgart, Stuttgart.

6. Kozárek, J., 2009: Vliv doby máčení na kvalitu provedené impregnace dřeva, Brno, $59 \mathrm{p}$.

7. Pražan, P.; Příkaský, F., 2007: Stav a vývoj pilařského průmyslu ve střední Evropě a ČR se zaměřením na malé a střední podniky. In D $\check{E} E V A \check{R} S K Y ́$ PRUMMYSL $V \check{C} R$, současný a budoucí vývoj pri̊myslu založeného na bázi dřeva. Sborník odborných příspěvků z celostátního semináře $v$ Brně.

8. *** CSN 49 1109, CSN EN 14081-1+A1, ČSN P ENV 1927-1, ČSN 73 2824-1, ČSN EN 14 080, ČSN EN 385, ČSN EN 390, ČSN EN 1194, ČSN EN 408

9. ***ČSN EN 1995-1-1, ČESKÝ NORMALIZAČNÍ INSTITUT, Praha 2006

10. ***http://www.euwid-holz.de/suche.html

The article:Rundholzpreise in Großbritannien sind weiter angestiegen

Text-Nr.: 005 Ausgabe: HZ48/2011 Ersch.-Dat.: 01.12.2011 [quoted 2012-02-10].

11. ***http://www.euwid-holz.de/suche.html

The article: Stammholzpreise in Schweden zuletzt gestiegen [quoted 2012-02-10].
12. ***http://www.euwid-holz.de/suche.html In Polen kostet sägefähiges Nadelrundholz im ersten Halbjahr 2012 deutlich mehr als 2011. Text-Nr.: 014 Ausgabe: HZ51/2011 Ersch.-Dat.: 22.12.2011. [quoted 2012-02-10].

13. ***http://www.euwid-holz.de/suche.html

The article: Schnittholzproduktion in Österreichim vierten Quartal deutlich rückläufig Text-Nr.: 010 Ausgabe: HZ48/2011 Ersch.-Dat.: 01.12.2011 - [quoted 2012-02$10]$.

14. ${ }^{* * *}$ http://www.euwid-holz.de/suche.html

The article: Druck auf BSH-Preise hat sich im Verlauf der vergangenen Wochen wieder erhöht. Text-Nr.:021 Ausgabe HZ51/2011 Esch.-Dat.:22.12.2011. [quoted 2012-02-10].

15. *** http://www.cwc.ca/index.php/en/wood-products/ glulam/manufacture [quoted 2013-02-27].

\section{Corresponding address:}

Ing. MICHAL ZEMAN

Czech University of Life Sciences Prague Faculty of Forestry and Wood Sciences Department of Wood Processing

Kamýcká 1176,

16521 PRAHA 6 - Suchdol, CZECH REPUBLIC

e-mail: zemiti@seznam.cz 